\title{
Pregnancy in rats is modulated by ganglionic cholinergic action
}

\author{
M Casais, S M Delgado, Z Sosa and A M Rastrilla \\ Universidad Nacional de San Luis, Chacabuco 917, San Luis, 5700, Argentina \\ Correspondence should be addressed to M Casais; Email: mcasais@unsl.edu.ar
}

\begin{abstract}
The control of ovarian steroidogenesis during pregnancy is mainly of endocrine origin. At present, there is little information about the influence of neural factors on the gestation physiology. The purpose of this work was to study the action of cholinergic agents in celiac ganglion upon the liberation of progesterone and ovarian androstenedione in the second half of pregnancy in rats. We used the ex vivo celiac ganglion-superior ovarian nerve-ovary integrated system (celiac ganglion-SON-ovary) that was incubated in buffer solution for $\mathbf{1 8 0} \mathbf{~ m i n}$, with the celiac ganglion and the ovary located in different compartments and linked by the SON.

The results obtained indicate that the control values of ovarian androstenedione vary according to the pregnancy day analyzed. The addition of acetylcholine in ganglion decreased the liberation of both steroids on Day 15 whereas at the end of pregnancy it decreased the liberation of androstenedione without modifying progesterone. Due to the effect observed with atropine and hexametonium, acetylcholine action might occur through unspecific ganglionic pathways (Days 15 and 21) or through muscarinic ganglionic receptors (Days 19 and 20). Thus, we conclude that the cholinergic sympathetic system from the celiac ganglion might be a fine modulator of the pregnancy physiology.

Reproduction (2006) 131 1151-1158
\end{abstract}

\section{Introduction}

Steroids play multiple roles in the physiological regulation of ovarian function, and locally produced steroid hormones may have important autocrine and paracrine effects in the ovary (Gibori 1993, Hillier et al. 1994).

The main steroids in pregnant rats are progesterone, secreted by the corpus luteum and androstenedione, secreted by the theca and interstitial cells. Both hormones provide a microenvironment adequate for the advance of pregnancy (Gibori 1993). Their synthesis is regulated by the hypophysial gonadotropins and modulated by placental factors (Rothchild 1981) among others (Villavicencio et al. 2002) and the neural effect mainly caused by the superior ovarian nerve (SON) (Lawrence \& Burden 1980, D'Albora et al. 2000, Aguado 2002). Using different experimental schemes, we have demonstrated that the SON modifies the liberation of ovarian steroids in different stages of life in rats (De Bortoli et al. 2000, Sosa et al. 2000, Casais et al. 2001, 2006, Forneris \& Aguado 2002). Fibers from the SON directly innervate the theca and secondary interstitial cells and they exert an indirect action on the corpus luteum (Erickson et al. 1985). Although such structure is not innervated, it possesses adrenergic $\beta_{1}$ and $\beta_{2}$ receptors, and it has been demonstrated that progesterone, its principal secretion product, is the most sensitive steroid to the neural action (Pesta et al. 1994, Miszkiel \& Kotwica 2001). In rats, during pseudopregnancy and cyclic periods, it has been demonstrated that the luteal cells increase progesterone release when they are stimulated by adrenergic agonists (Norjavaara et al. 1989, Sosa et al. 2000). However, during pregnancy, they do not respond to direct adrenergic stimulation. However, when using the ex vivo celiac ganglion-SONovary system, the action of adrenergic agents in celiac ganglion modified the liberation of progesterone during the second half of pregnancy (Casais et al. 2001).

Most of the fibers that constitute the SON derive from main neurons of the celiac ganglion which is a component of the prevertebral ganglion chain and it is a modulation center in the pathway of the afferent and efferent fibers between the central nervous system and the ovary (Baljet \& Drukker 1979, Lawrence \& Burden 1980, Cardinali et al. 1983, Klein \& Burden 1988).

It has been demonstrated that in the sympathetic ganglia its preganglion neurotransmitter is acetylcholine (Klein \& Burden 1988) and that it possesses nicotinic and muscarinic cholinergic receptors in the principal cells as well as muscarinic receptors in other neuronal populations (Matthews 1989, Reid \& Perry 1995, Prud'Homme et al. 1999). The stimulation of such receptors causes modifications in the steroids' liberation, in cyclic rats 
(Sosa et al. 2004) and prepubertal rats (Delgado et al. 2004) as well as in male rats (Zhu et al. 2002).

Without attempting to oversimplify the complex problem of ganglionic functioning and regulation, the aim of this work was to demonstrate the effect of cholinergic agents in celiac ganglion upon the release of ovarian progesterone and androstenedione during the second half of pregnancy in two different stages: (1) on Day 15 when the corpus luteum is at its maximum in the secretion of progesterone, and the placenta constitutes the main source of androstenedione; (2) at the end of pregnancy when the luteal regression starts with the subsequent decrease of progesterone. In this stage, androstenedione, a well-known luteotropic agent, is secreted by the ovarian interstitial cells that are directly innervated.

For this, we used the celiac ganglion-SON-ovary system previously standardized in our laboratory (Casais et al. 2001). This system permits an in vitro emulation of in vivo conditions, preserving innervation and paracrine and autocrine regulations without the humoral influence.

\section{Materials and Methods}

\section{Animals}

Adult female rats bred in our laboratory (originally Holtzman strain) and weighing $220 \pm 50 \mathrm{~g}$ were used. The rats were housed under controlled light (lights on from 0700 to $1900 \mathrm{~h})$ and temperature $\left(24 \pm 2{ }^{\circ} \mathrm{C}\right)$ conditions and water and food provided ad libitum (rat chow-Cargil SACl; Saladillo, Buenos Aires, Argentina).

To induce pregnancy, female rats were caged individually with fertile males beginning on the afternoon of pro-estrus. Positive mating was verified on the following morning by identifying sperm or copulation plugs in the vagina. This day was designated as Day 0 of pregnancy. In our laboratory rats usually give birth on Day 22. Animals were handled according to the procedures approved in the UFAW Handbook on the Care and Management of Laboratory Animals (1999) and the Guide for Animal Use and Handling of the National University of San Luis (number protocol: B17/04, ordinance CD 006/02).

\section{Chemicals}

L-acetylcholine hydrochloride, L-hexametonium, atropine, dextrose, ascorbic acid, bovine serum albumin fraction $V$ were purchased by the Sigma Chemical Co (St. Louis, Mo, USA). 1,2,6,7-[ $\left.{ }^{3} \mathrm{H}\right]$ Progesterone $(107.0 \mathrm{Ci} / \mathrm{mmol})$ and $1,2,6,7-\left[{ }^{3} \mathrm{H}\right]$ androst (4-ene-3,17) dione $(115.0 \mathrm{Ci} / \mathrm{mmol})$ were provided by New England Nuclear Products (Boston, MA, USA). Other reagents were of analytical grade.

\section{Experimental procedure}

Groups of six animals on Days 15, 19, 20 and 21 of pregnancy were used. Surgical operations and standardization of incubation conditions of the celiac ganglionSON-ovary system were performed as previously reported (Casais et al. 2001). Briefly, under atmosphere of ether anesthesia, the system was removed from each animal in 1-2 min. In each of the experimental procedures the piece of tissue removed consisted, of the left ovary, the fibers that constitute the $\mathrm{SON}$, inserted in the suspensory ligament, and the celiac ganglion accompanied by some small ganglia sorrounding it. The system as a whole was cleaned with incubation solution and placed immediately in a cuvette with two compartments. Each compartment contained $2 \mathrm{ml}$ of Buffer Krebs Ringer-bicarbonate $\mathrm{pH} 7.4$, with the addition of $0.1 \mathrm{mg}$ glucose $/ \mathrm{ml}$ and $0.1 \mathrm{mg}$ albumin $/ \mathrm{ml}$, as has been described for incubation of ovaries in other in vitro systems (Ferruz et al. 1992). The celiac ganglion was placed in one compartment and the ovary in the other, connected by the SON, which had to be kept moist with the work solution.

The system was pre-incubated at $37{ }^{\circ} \mathrm{C}$ in Krebs Ringer's buffer for 30 min under saturated $\mathrm{O}_{2} / \mathrm{CO}_{2}$ (95:5\%) atmosphere. The end of the pre-incubation period was considered as incubation time 0 . At this time, the buffer was changed in both compartments and periodical extractions were made from the ovarian compartment at 30, 60, 120 and $180 \mathrm{~min}$ for the determination of progesterone and androstenedione release. $0.1 \mathrm{mg}$ ascorbic acid/ml (in Krebs Ringer) was added as an antioxidant agent to the ganglion compartment at incubation time 0 .

The values of progesterone and androstenedione released under these conditions were considered as control (control group). For the experimental groups acetylcholine (Ach) as cholinergic agonist, hexametonium $\left(\mathrm{C}_{6}\right)$ as nicotinic antagonist and atropine (At) as muscarinic antagonist were used. The cholinergic agents were given individually in the ganglionic compartment at incubation time 0 . That is, for each of them an experiment under similar conditions to the control group was carried out with addition of the studied cholinergic agents. The different substances were dissolved in equal concentrations $\left(10^{-6} \mathrm{~mol} / \mathrm{l}\right)$ and volumes $(2 \mathrm{ml})$ of Krebs Ringer's solution plus ascorbic acid. The dose of drug was chosen according to previous works of our research group with adrenergic and cholinergic agents whose standardization was done by means of dose/response curves (Sosa et al. 2000, 2004, Casais et al. 2001, Delgado et al. 2004). Besides, the appropriate bibliography such as Reid \& Perry (1995) was previously checked.

The samples of liquid from the ovarian compartment were stored in a freezer at $-20{ }^{\circ} \mathrm{C}$ until hormonal assay. Progesterone and androstenedione were measured by radioimmunoassay (RIA), which was previously validated 
(Bussman \& Deis 1979). The variability and crossreaction of this RIA have been previously reported too (Bussman \& Deis 1979). The sensitivity of the progesterone assay is less than $5 \mathrm{ng}$ progesterone $/ \mathrm{ml}$ and the interand intra-assay coefficients of variation were less than $10 \%$. The androstenedione assay sensitivity was less than $0.01 \mathrm{ng}$ androstenedione $/ \mathrm{ml}$. The intra-assay coefficients of variation for all the assays were less than $10.0 \%$.

The results were expressed as pg of progesterone per $\mathrm{mg}$ of ovarian tissue (Ppg/mg ovary) against time of incubation and as pg of androstenedione per $\mathrm{mg}$ of ovarian tissue $\left(\mathrm{A}_{2} \mathrm{Ppg} / \mathrm{mg}\right.$ ovary) against time of incubation. The corresponding corrections were made in all cases, taking into consideration the volume extracted in each tested period.

\section{Statistical analysis}

Comparisons between the means of two groups were carried out using the Student's $t$ test. For multiple comparisons the analysis of the variance (ANOVA I), followed by Duncan's multiple range test, was used. A level of $P<0.05$ was accepted as being statistically significant (Snedecor \& Cochram 1976).

\section{Results}

\section{Ovarian progesterone release by ganglionic cholinergic action in the second half of pregnancy}

The celiac ganglion-SON-ovary system of rats with $15,19,20$ and 21 days of pregnancy was used in order to investigate if acetylcholine and its antagonists $\left(10^{-6} \mathrm{~mol} / \mathrm{l}\right)$, in celiac ganglion, had an influence on the ovarian progesterone release.

The results of each experiment are expressed with respect to the corresponding control group. On Day 15 of pregnancy, cholinergic agents caused a decrease in the progesterone release. The release was significant with acetylcholine at 30, 120 and $180 \mathrm{~min}(\bullet P<0.05)$, with hexametonium only at $180 \mathrm{~min}(\bullet P<0.05)$ and with atropine at all the studied times $(* P<0.01)$ (Fig. 1 A).

On Day 19 of pregnancy, acetylcholine added to celiac ganglion did not modify ovarian progesterone release. Hexametonium and atropine decreased the release at short times $\left(C_{6:}: 30\right.$ and $60 \mathrm{~min} \bullet P<0.05$ and At: 30 min $\bullet P<0.05$ ) (Fig. 1 B).

On Day 20 of pregnancy, acetylcholine did not produce any effect on the ovarian progesterone release, whereas hexametonium increased it significantly only at $180 \mathrm{~min}(\bullet P<0.05)$, and atropine decreased it at long times (120 and $180 \min (\bullet P<0.05)$ (Fig. 1C).

On Day 21 of pregnancy, acetylcholine did not produce any effect on the ovarian progesterone release, whereas hexametonium increased it significantly at 60 min $(* P<0.01)$, and atropine until $120 \mathrm{~min}(30$ and $60 \mathrm{~min} \bullet P<0.05 ; 120 \mathrm{~min} * P<0.01)$ (Fig. 1D).

\section{Ovarian androstenedione release by ganglionic cholin- ergic action in the second half of pregnancy}

Having demonstrated that the celiac ganglion-SONovary system has its own neural tone in the case of progesterone release (Casais et al. 2001) for a gland like corpus luteum, which is not directly innervated by the $\mathrm{SON}$, it seems necessary to investigate this aspect in the theca-interstitial cells, which are producers of androstenedione (control values) since they are innervated by the neural system mentioned (Erickson et al. 1985). The higher androstenedione release values were those corresponding to Day 21 of pregnancy, and when compared with this day, the androgen decreased on Day 15 after $120 \mathrm{~min}(120 \mathrm{~min} \bullet P<0.05$ and $180 \mathrm{~min}$ $* P<0.01)$, and on Days 19 and 20, at all the studied times $(* P<0.01)$.

In relation to the ganglion cholinergic action, on Day 15 of pregnancy, ovarian androstenedione release significantly decreased not only with acetylcholine and hexametonium until $120 \mathrm{~min}$ (30 and $60 \mathrm{~min} * P<0.01$ and $120 \mathrm{~min} \bullet P<0.05)$ but also with atropine at all the studied times (until $120 \mathrm{~min}^{*} P<0.01$ and $180 \mathrm{~min}$ - $P<0.05$ ) (Fig. 2A).

On Day 19 of pregnancy, acetylcholine and hexametonium decreased ovarian androstenedione release (Ach: 30 and $180 \mathrm{~min} \bullet P<0.05$ and $C_{6}: 30,60$ and $180 \mathrm{~min} * P<0.01$ and $120 \mathrm{~min} \bullet P<0.05$ ) whereas atropine stimulated it at all the studied times $\left({ }^{*} P<0.01\right)$ (Fig. 2B).

On Day 20 of pregnancy, acetylcholine added to celiac ganglion decreased androstenedione release at all times (until $120 \mathrm{~min} \bullet P<0.05$ and $180 \mathrm{~min} * P<0.01$ ). On the other hand, the antagonists increased it, hexametonium after $120 \mathrm{~min}(\bullet P<0.05)$ and atropine at all times (30 and $180 \mathrm{~min} \bullet P<0.05$ and 60 and $120 \min ^{*} P<0.01$ ) (Fig. 2C).

On Day 21 of pregnancy, ovarian androstenedione release decreased in the presence of acetylcholine in celiac ganglion (30 and $120 \mathrm{~min} \bullet P<0.05$ and 60 and 180 min $* P<0.01)$ as well as with hexametonium at $180 \mathrm{~min}(\bullet P<0.05)$ and atropine $(30,120$ and $180 \mathrm{~min}$ - $P<0.05$ ) (Fig. 2D).

\section{Discussion}

The results of this study indicate that the addition of acetylcholine in ganglion decreased the liberation of both progesterone and androstenedione on Day 15 of gestation whereas at the end of pregnancy, it decreased the liberation of androstenedione without modifying the decreased levels of progesterone. Due to the effect observed with atropine and hexametonium, acetylcholine action might occur through unspecific ganglionic pathways (Days 15 and 21) or through muscarinic ganglionic receptors (Days 19 and 20). These findings indicate that the ganglion response to the cholinergic 

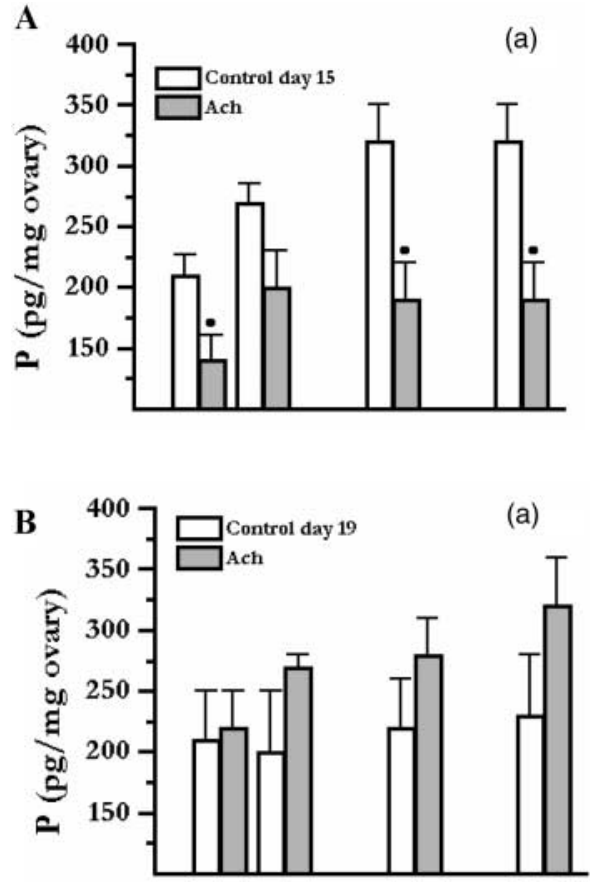

C

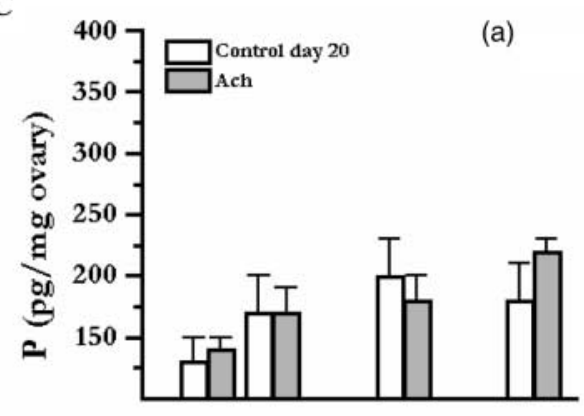

D

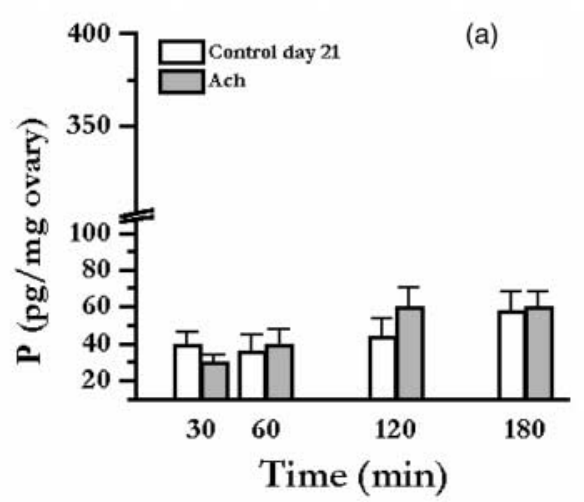

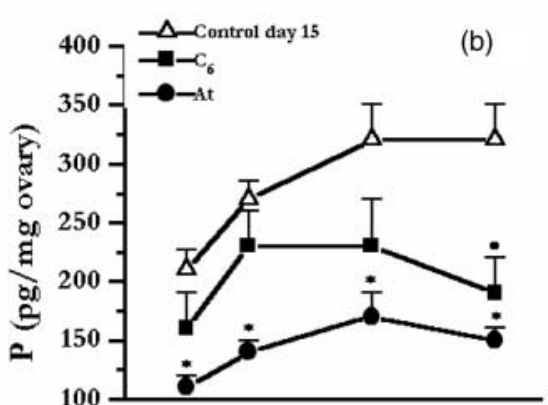

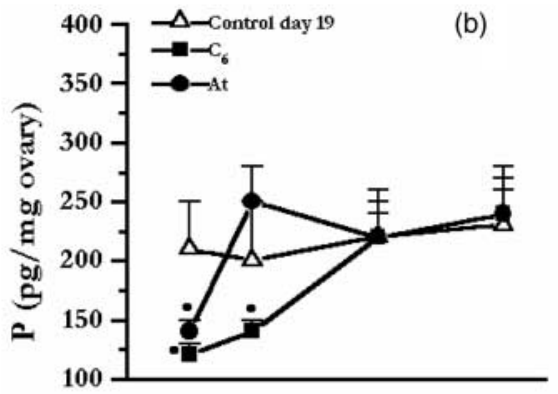

(b)
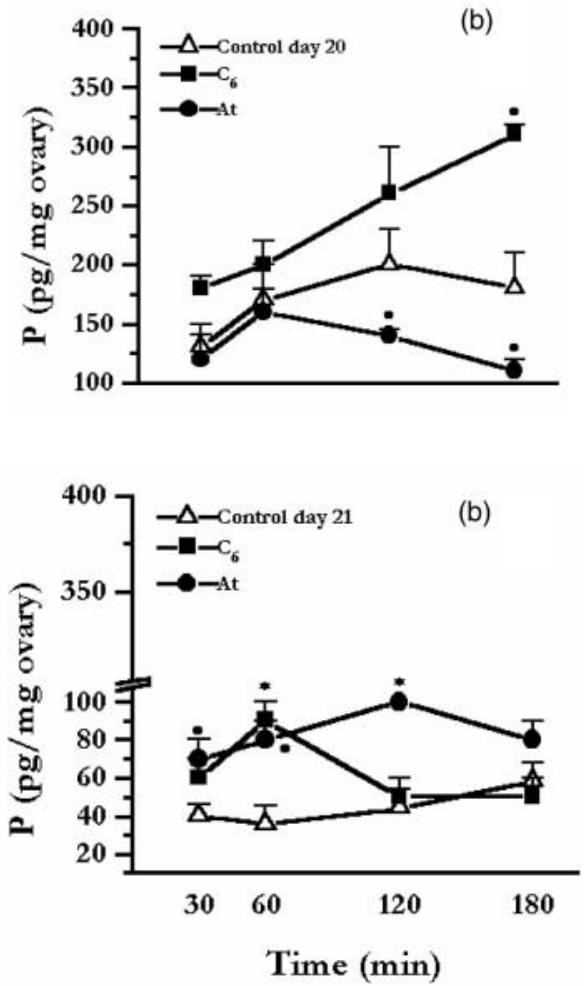

Figure 1 Effect of cholinergic agonist (a) and antagonists (b) in ganglion compartment on ovarian progesterone (P) release in the celiac ganglionSON-ovary system obtained from pregnant rats on Day 15 (A), Day 19 (B), Day 20 (C) and Day 21 (D). The systems were incubated in buffer Krebs Ringer, plus $0.1 \mathrm{mg}$ ascorbic acid $/ \mathrm{ml}$ at $37{ }^{\circ} \mathrm{C}$ in an atmosphere of $95 \% \mathrm{O}_{2}-5 \% \mathrm{CO}_{2}$ for $180 \mathrm{~min}$ without (control) and with cholinergic agents in $10^{-6} \mathrm{~mol} / /$ concentration added to the ganglionic compartment (experimental group). Ach: acetylcholine; $\mathrm{C}_{6}$ : hexametonium; At: atropine. Results are expressed as mean \pm S.E.M. of six animals per experimental group from respective control. ${ }^{*} P<0.01$ and $\bullet P<0.05$. 

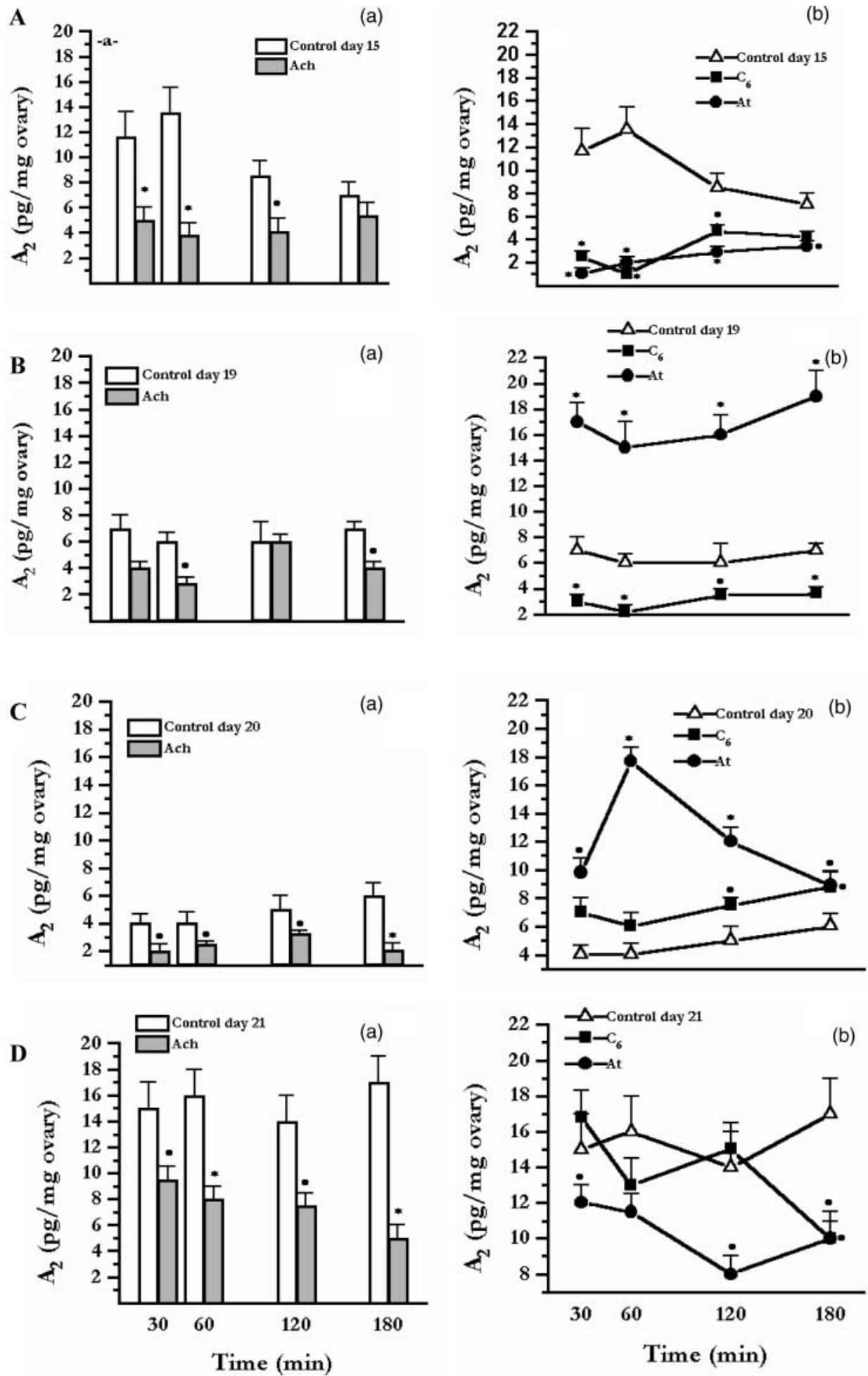

Figure 2 Effect of cholinergic agonist (a) and antagonists (b) in ganglion compartment on ovarian androstenedione $\left(\mathrm{A}_{2}\right)$ release in the celiac ganglionSON-ovary system obtained from pregnant rats on Day 15 (A), Day 19 (B), Day 20 (C) and Day 21 (D). The systems were incubated in buffer Krebs Ringer, plus $0.1 \mathrm{mg}$ ascorbic acid/ml at $37^{\circ} \mathrm{C}$ in an atmosphere of $95 \% \mathrm{O}_{2}-5 \% \mathrm{CO}_{2}$ for $180 \mathrm{~min}$ without (control) and with cholinergic agents in $10^{-6} \mathrm{~mol} / \mathrm{l}$ concentration added to the ganglionic compartment (experimental group). Ach: acetylcholine; $\mathrm{C}_{6}$ : hexametonium; At: atropine. Results are expressed as mean \pm S.E.M. of six animals per experimental group from respective control. ${ }^{*} P<0.01$ and $\bullet P<0.05$. 
action depends on the dynamics of the processes that occur during pregnancy.

Gibori \& Sridaran (1981) have shown that the ovary produces androgens during the first half of pregnancy whereas during the second half they are produced by placenta. Before delivery, the ovary takes control again depending on the luteinizing hormone $(\mathrm{LH})$ ( Bogovich et al. 1981, Gibori \& Sridaran 1981). When working with the celiac ganglion-SON-ovary system during the second half of pregnancy under control conditions, high values of androstenedione are observed on Day 15 which decrease on Days 19 and 20. On Day 21, values increase and they are higher than on Day 15. It is important to emphasize that the high levels of androgen on Day 21 may be due to the new follicles necessary for the establishment of the post-delivery estral cycle. The variability in the androstenedione liberation on the different studied days of pregnancy was also observed with progesterone under the same control conditions (Casais et al. 2001). These results permit us to assume that the celiac ganglion-SON-Ovary system constitutes a viable and functional entity with its own autonomic tone, which permits the use of antagonists in celiac ganglion without the simultaneous addition of the agonist.

When we analyzed the action of acetylcholine in celiac ganglion upon the liberation of ovarian steroids we observed different responses.

On Day 15, the liberation of progesterone and androstenedione is inhibited at all the studied times. Considering the effect of the antagonists, it can be concluded that in this case the ganglionic action of acetylcholine is through an unspecific way. The existence of these unspecific ganglionic effects could be the consequence of the cholinergic antagonists, action over the specific receptors present on the peptidergic and small intensely fluorescent interneurons. Thus, these neurons could liberate different neurotransmitters which could eventually provoke the same effect of the agonist when acting over receptors present on other interneurons or on the postganglionic neurons. Therefore, we could suggest that the output response of the postganglionic neurons is due to the contribution, regulation and integration of the behavior of different functional populations in the ganglion.

These results are in agreement with those reported by Sosa et al. (2004) for progesterone in Diestrus 1 when the predominant ovarian structure is the corpus luteum, and for progesterone and androstenedione in rats of 30 days of age (Delgado et al. 2004). In both studies, they use the same system. In both cases, acetylcholine caused the same effect through a similar ganglionic mechanism. The inhibitory effect of acetylcholine might be due to different factors such as the lowest availability of noradrenaline in ovary as it was observed on Diestrus 1 (Sosa et al. 2004), the ovarian increase of nitric oxide that occurs in prepubertal rats in similar circumstances
(Delgado et al. 2004) or the liberation of some other neurotransmitter with inhibiting characteristics (Erdö et al. 1985, Garraza et al. 2004). We cannot discard the possibility that an intrinsic gonadotropin-releasing hormone $(\mathrm{GnRH})$ system might be being stimulated in the ovary by ganglionic cholinergic action, via SON, which exerts a well-known inhibitory effect on the luteal steroidogenesis during pregnancy (Sridaran et al 1999, Yang et al. 2003).

Towards the end of gestation (Days 19, 20 and 21), though acetylcholine did not modify the liberation of progesterone, it inhibited the liberation of androstenedione.

In relation to progesterone, an effect similar to that caused by acetylcholine was observed by Casais et al. (2001) when adding noradrenaline in celiac ganglion, by which the steroidogenic response to neural action gradually decreases with the establishment of physiological luteal regression at the end of gestation. Likewise, Sosa et al. (2004) demonstrated that the secretion of ovarian progesterone was not modified by the addition of the acetylcholine to the ganglion compartment on Diestrus 2 and pro-estrus when the corpora lutea start regression. However, the existence of neural output is demonstrated by the effect of the antagonists, mainly atropine, which is in general an indication of the system viability and particularly, of the participation of the ganglionic muscarinic receptors mainly at the level of the secondary interneurons. In relation to this, Gejman \& Cardinali (1983) suggested that muscarinic cholinergic neurotransmission in bovine and rat superior cervical ganglia may be affected by hormones. However, Anglin \& Brooks (2003) have found that in the superior cervical ganglion, the ganglionic content of tyrosine hydroxylase increases and the norepinephrine transporter decreases on Day 20 of pregnancy, and that the changes depend not only on the changes of estrogen or progesterone.

In relation to the inhibitory action of acetylcholine in celiac ganglion on the liberation of androstenedione, this action would be exerted through muscarinic ganglionic receptors on Days 19 and 20, while on Day 21 it would be exerted through an unspecific pathway. The luteotropic effect of androstenedione has been widely demonstrated in different experimental schemes (Carrizo et al. 1994, Hillier et al. 1994, Thordarson et al. 1997, Goyeneche et al. 2002) and even in the celiac ganglion-SON-ovary via SON (Casais et al. 2006). Our results indicate that the ganglionic cholinergic action, mainly on the liberation of androstenedione, would act favoring the luteal regression occurring at the end of gestation which is necessary for the delivery to occur.

The present work, permit us to conclude that the peripheral nervous system might be a fine modulator of pregnancy. 


\section{Acknowledgements}

This manuscript is dedicated to the memory of PhD Luis I. Aguado (1946-2003).

This work was supported by Grant 3711/92 from CONICET (Consejo Nacional de Investigaciones Científicas y Técnicas, Argentina) and by Grant 9302 from Universidad Nacional de San Luis, Argentina. We thank Dr. R.P. Deis who provided the progesterone and androstenedione antiserums. We thank Engineer Mario Baudino for his informatic assistance. We also acknowledge Luis Villegas for his technical assistance. This work is part of the doctoral thesis of Marilina Casais.

\section{References}

Aguado LI 2002 Role of the central and peripheral nervous system in the ovarian function. Microscopic Research and Technique 59 462-467.

Anglin JC \& Brooks VL 2003 Tyrosine hydroxylase and norepinephrine transporter in sympathetic ganglia of female rats vary with reproductive state. Autonomic Neuroscience 105 (Suppl 1) 8-15.

Baljet B \& Drukker J 1979 The extrinsic innervation of the abdominal organs in the female rat. Acta Anatomica 104 (Suppl 3) 243-267.

Bogovich K, Richards JS \& Reichet LE 1981 Obligatory role of LH in the initiation of preovulatory follicular growth in the pregnant rat: Specific effects of hCG and follicle stimulating hormone on LH receptors and steroidogenesis in theca, granulosa and luteal cells. Endocrinology 109 860-867.

Bussmann LE \& Deis RP 1979 Studies concerning the hormonal induction of lactogenesis by prostaglandin F2 $\alpha$ in pregnant rats. Journal of Steroid Biochemistry and Molecular Biology 11 1485-1489.

Cardinali DP, Vacas MI, Gejman PV, Pisarev MA, Barontini M \& Boado RJ 1983 The sympathetic superior cervical ganglia as "Little Neuroendocrine Brains". Acta Physiol Latin 33 205-221.

Carrizo D, Rastrilla A, Tellería C \& Aguado L 1994 Androstenedione stimulates progesterone production in corpora lutea of pregnant rats: an effect not mediated by oestrogen. Journal of Steroid Biochemistry and Molecular Biology 51 191-197.

Casais M, Sosa ZY, Rastrilla AM \& Aguado LI 2001 Coeliac ganglion adrenergic activity modifies ovarian progesterone during pregnancy: its inter-relationship with LH. Journal of Endocrinology 170 575-584.

Casais M, Delgado SM, Sosa Z \& Rastrilla AM 2006 Involvement of the coeliac ganglion in the luteotrophic effect of androstenedione in late pregnant rats. Reproduction 131 361-368.

D'Albora H, Lombide P \& Ojeda S 2000 Intrinsic neurons in the rat ovary: an immunohistochemical study. Cell Tissue Rs. 300 47-56.

De Bortoli MA, Garraza MH \& Aguado LI 2000 Epinephrine intracerebroventricular stimulation modifies the LH effect on ovarian progesterone and androstenedione release. Journal of Steroid Biochemistry and Molecular Biology 74 19-24.

Delgado SM, Sosa Z, Dominguez NS, Casais M, Aguado LI \& Rastrilla AM 2004 Effect of the relation between neural cholinergic action and nitric oxide on ovarian steroidogenesis in prepubertal rats. Journal of Steroid Biochemistry and Molecular Biology 91 139-145.

Erdö SL, Varga B \& Horvath E 1985 Effect of local GABA administration on rat ovarian blood flow, and on progesterone and estradiol secretion. European Journal of Pharmacology 111 397-404.

Erickson GF, Magofin DA, Dyer CA \& Hofeditz C 1985 The ovarian androgen producing cell: a review of structure/function relationships. Endocrinology Review 6 371-382.

Ferruz J, Ahmed CE, Ojeda SR \& Lara HE 1992 Norepinephrine release in the immature ovary is regulated by autoreceptors and neuropeptide Y. Endocrinology 130 1345-1351.

Forneris ML \& Aguado LI 2002 Neonatal superior ovarian nerve transection disturbs the ciclic activity of the female rats. Journal of Steroid Biochemistry and Molecular Biology 82 75-82.
Garraza MH, Aguado LI \& De Bortoli MA 2004 In vitro effect of neuropeptides on ovary or celiac ganglion affects the release of progesterone from ovaries in the rat. Med Sci Monit 10 (Suppl 12) BR440-446.

Gejman PV \& Cardinali P 1983 Hormone effect on muscarinic cholinergic binding in bovine and rat sympathe superior cervical ganglia. Life Science 32 965-972.

Gibori G 1993 The corpus luteum of pregnancy. In The Ovary, ch 14, pp 261-317. Eds EY Adashi \& PCK Leung. New York: Raven Press.

Gibori G \& Sridaran R 1981 Sites of androgen and estradiol production in the second half of pregnancy in the rat. Biology of Reproduction 24 249-256.

Goyeneche A, Calvo V, Gibori G \& Tellería C 2002 Androstenedione interferes in luteal regression by inhibiting apoptosis and stimulating progesterone production. Biology of Reproduction 66 1540-1547.

Hillier SG, Whitelaw PF \& Smyth CD 1994 Follicular estrogen synthesis: The "two cell, two gonadotropin" model revisited. Molecular and Cellular Endocrinology 10 51-54.

Klein CM \& Burden HW 1988 Anatomical localization of afferent and postganglionic sympathetic neurons innervating the rat ovary. Neuroscience Letters 85 217-222.

Lawrence IEJ \& Burden HW 1980 The origin of the extrinsic adrenergic innervation to the rat ovary. Anatomical Record 196 51-55.

Matthews MR 1989 Small, intensely fluorescent cells and the paraneuron concept. Journal Electronic Microscopic Technique 12 (4) 408-416.

Miszkiel G \& Kotwica J 2001 Mechanism of action of noradrenaline on the secretion of progesterone and oxytocin by the bovine corpus luteum in vitro. Acta Veterinaria Hungarica 49 39-51.

Norjavaara E, Rosberg S, Gafvels M, Boberg BM \& Selstam G 1989 Beta adrenergic receptor concentration and subtype in the corpus luteum of the adult pseudopregnant rat. Journal of Reproduction and Fertility 86 567-575.

Pesta M, Muszynska A, Kucharski J, Superata J \& Kotwica J 1994 Betaadrenergic receptors in corpora lutea from different stages of the estrous cycle in conscious and slaughtered cattle. Biology of Reproduction 50 215-221.

Prud'Homme MJ, Houdeau E, Serghini R, Tillet Y, Schemann M \& Rousseau JP 1999 Small intensely fluorescent cells of the rat paracervical ganglion synthesize adrenaline, receive afferent innervation from postganglionic cholinergic neurones, and contain muscarinic receptors. Brain Research 821 (Suppl 1) 141-149.

Reid SG \& Perry SF 1995 Cholinoceptor-mediated control of catecholamine release from chromaffin cells in the American eel, Anguilla rostrata. Journal of Comparative Physiology. B, Biochemical, Systemic, and Environmental Physiology 165 (Suppl 6) 464-470.

Rothchild I 1981 The regulation of mammalian corpus luteum. Recent Prog. Horm. Res. 37 183-186.

Snedecor GW \& Cochram WG 1976 Statistical Methods. Ames, lowa: The lowa State University Press.

Sosa ZY, Casais M, Rastrilla AM \& Aguado L 2000 Adrenergic influences on the coeliac ganglion affect the release of progesterone from cycling ovaries: Characterisation of an in vitro system. Journal of Endocrinology 166 307-318.

Sosa ZY, Delgado M, Casais M, Aguado LI \& Rastrilla AM 2004 Release of ovarian progesterone during the rat oestrous cycle by ganglionic cholinergic influence. The role of norepinephrine. Journal of Steroid Biochemistry and Molecular Biology 91 179-184.

Sridaran R, Lee MA, Haynes L, Srivastava RK, Ghose M, Sridaran G \& Smith CJ 1999 GnRH action on luteal steroidogenesis during pregnancy. Steroids 64 618-623.

Thordarson G, Galosy S, Gudmundsson GO, Newcomer B, Sridaran R \& Talamantes F 1997 Interaction of mouse placental lactogens and androgens in regulating progesterone release in cultured mouse luteal cells. Endocrinology 138 (Suppl 8) 3236-3241.

Universities Federation for Animal Welfare 1999 UFAW Handbook on the Care and Management of Laboratory Animals, Vol 1 - Terrestrial Vertebrates. Ed T Poole. Oxford: Blackwell Science. 
Villavicencio A, Iñiguez G, Johnson MC, Gabler F, Palomino A \& Vega M 2002 Regulation of steroid synthesis and apoptosis by insulin-like growth factor I and insulin-like growth factor binding protein 3 in human corpus luteum during the midluteal phase. Reproduction $\mathbf{1 2 4}$ 501-508.

Yang H, Bhat G, Wadley R, Wright K, Chung B, Whittaker J, Dharmarajan A \& Sridaran R 2003 Gonadotropin-releasing hormone-agonist inhibits synthesis of nitric oxide and steroidogenesis by luteal cells in the pregnant rat. Biology of Reproduction $\mathbf{6 8}$ 2222-2231.
Zhu C, Palmada MN, Aguado LI \& Cavicchia JC 2002 Administration of acetylcholine to the spermatic nerve plexus inhibits testosterone secretion in an in vitro isolated rat testis-nerves plexus system. International Journal of Andrology 25 134-138.

Received 4 October 2005

First decision 13 December 2005

Revised manuscript received 4 January 2006

Accepted 7 March 2006 